\title{
Degradation Prevalence Study of Field-Aged Photovoltaic Modules Operating Under Kenyan Climatic Conditions
}

\author{
Macben Makenzi ${ }^{1}$, Nelson Timonah $^{2}$, Mutua Benedict ${ }^{3}$, Ismael Abisai ${ }^{4}$ \\ ${ }^{1}$ Mechatronic Department, Jomo Kenyatta University of Agriculture and Technology, Nairobi, Kenya \\ ${ }^{2}$ Physics Department, Jomo Kenyatta University of Agriculture and technology, Nairobi, Kenya \\ ${ }^{3}$ Faculty of Engineering and Technology, Egerton University, Nakuru, Kenya \\ ${ }^{4}$ Ubbink East Africa Ltd, Naivasha, Kenya
}

Email address:

macbenmm@gmail.com (M. Makenzi)

\section{To cite this article:}

Macben Makenzi, Nelson Timonah, Mutua Benedict, Ismael Abisai. Degradation Prevalence Study of Field-Aged Photovoltaic Modules Operating Under Kenyan Climatic Conditions. Science Journal of Energy Engineering. Vol. 3, No. 1, 2015, pp. 1-5.

doi: $10.11648 /$ j.sjee.20150301.11

\begin{abstract}
Photovoltaic (PV) modules deployed outdoors can degrade due to exposure to the various elements. This includes exposure to UV light, a range of fluctuating temperatures and humidity and exposure to a range of operating currents and voltages. Different weather conditions have an important influence on degradation rate. Evidence indicates that both degradation and failure mechanisms are location dependent. This paper presents a research investigating the prevalence of various forms of physical degradation experienced by photovoltaic panels which have been in operation in Kenya under various climatic conditions. To study degradation of PV systems, identification and analysis of modules that had been deployed in various locations in Kenya, and which had been in operation for at least the last 2 years was carried out. Imaging instruments were used to study visible signs of weathering and other physical defects. The results indicated that despite the fact that panels are designed to operate in outdoor environment, numerous cases do exist whereby the panels degrade physically, in various ways, and consequently exhibit total failure, diminished performance or just physical manifestation of wear. Apart from manufacturer defects, user ignorance on installation and usage was also proved to contribute to the diminished life span of some panels.
\end{abstract}

Keywords: Degradation, Photovoltaic, Field-Aged Modules

\section{Introduction}

Long term performance of photovoltaic (PV) systems is vital to their continuing success in the market place. The gradual energy output loss over long periods of time is a major concern to all renewable energy stakeholders. A wide variety of degradation rates has been reported in literature with respect to technologies, age, manufacturers, and geographic locations [1].

PV modules are degraded by ambient temperature and humidity; moreover, these factors can accelerate the degradation. Moisture can diffuse into photovoltaic (PV) modules through their breathable back sheets or their ethylene vinyl acetate (EVA) sheets [2]. When in service in hot and humid climates, PV modules experience changes in the moisture content, the overall history of which is correlated with the degradation of the module performance [2]. If moisture begins to penetrate the polymer and reaches the solar cell, it can weaken the interfacial adhesive bonds, resulting in delamination [3] and increased numbers of ingress paths, loss of passivation [4], and corrosion of solder joints [5,6,7]. Significant losses in PV module performance are caused by the corrosion of the cell, that is, the $\mathrm{Si}-\mathrm{Nx}$ antireflection coating, or the corrosion of metallic materials, that is, solder bonds and Ag fingers [8, 9].

A thorough understanding of the forms of physical degradation experienced by solar modules and their relationship to various climatic conditions, is essential to all stakeholders i.e. private consumers, utility companies, integrators, investors, and researchers alike. Financially, degradation of a PV module or system is equally important, because a higher degradation rate translates directly into less power produced and, therefore, reduces future cash flows [10]. Technically, degradation mechanisms are important to 
understand because they may eventually lead to failure [11].

It is not well known how long modules last after their installation. Manufacturer warranties often guarantee $80 \%$ maximum power for 25 years; however relatively few PV modules have been in use for that long. As a result, there is a limited amount of data on PV module lifetimes. Different methodologies have been used to study degradation effects including both indoor and field measurements. Photovoltaic module manufacturers usually make efforts to eliminate the impact of short-term and long-term environment-induced degradation, but the difficulty in correlating indoor with outdoor testing at local conditions, poses a great challenge.

Degradation studies are more often than not based on various scientific studies that are typically grounded on general conditions. Manufacturers usually expose their products to accelerated tests which rarely depict the actual environment that the panel will eventually end up operating in after outdoor deployment.

As such, there exists a huge knowledge gap on the degradation forms and mechanisms of solar panels over medium to long term usage. A larger gap tending towards almost total exclusion of this knowledge, for the Kenyan environment, does exist. The present article presents an empirical study of PV panels, in their natural operating environments and having been in operation over an extended period, to investigate the degradation forms, their prevalence and their correlation between various climate conditions experienced in Kenya.

\section{Procedures}

Solar panels were sourced from different regions in the country, implying that each of the panels was exposed to a specific set of climatic conditions. The panels also varied in age. The oldest panel analysed had been in operation for 27 years whilst the youngest had an operation lifetime age of 9 years as at the time of analysis.

Precipitation and temperature data information for the various areas from which the photovoltaic modules were sourced from was obtained and used for zoning sample source regions.

A Nikon D800, 36.3 megapixels FX-format HD-SLR was used for visual imaging of defects and degradation manifestations.

\section{Results}

A brief description of the seventeen PV-module samples used in the investigation is outlined in Table 1 below. Information on location, age and climate of the area is listed.

Table 1. Information on Solar Modules Samples.

\begin{tabular}{lllll}
\hline $\begin{array}{l}\text { Module } \\
\text { I.D }\end{array}$ & $\begin{array}{l}\text { Installation } \\
\text { Location }\end{array}$ & $\begin{array}{l}\text { Age } \\
\text { (Years) }\end{array}$ & $\begin{array}{l}\text { Temperature } \\
\text { Zone }\end{array}$ & Rain Zone \\
\hline S 1 & Bunyore & 27 & Zone 2 & zone 1 \\
S 2 & Tala & 23 & Zone 2 & Zone 3 \\
S3 & Sultan Hamud & 21 & Zone 3 & Zone 3 \\
S 4 & Voi & 17 & Zone 3 & Zone 3 \\
\hline
\end{tabular}

\begin{tabular}{lllll}
\hline $\begin{array}{l}\text { Module } \\
\text { I.D }\end{array}$ & $\begin{array}{l}\text { Installation } \\
\text { Location }\end{array}$ & $\begin{array}{l}\text { Age } \\
\text { (Years) }\end{array}$ & $\begin{array}{l}\text { Temperature } \\
\text { Zone }\end{array}$ & Rain Zone \\
\hline S 5 & Homa Bay & 17 & Zone 2 & Zone 1 \\
S 6 & Kisii & 20 & Zone 2 & Zone 1 \\
S 7 & Kisii & 22 & Zone 2 & Zone 1 \\
S 8 & Migori & 15 & zone 3 & zone 1 \\
S 9 & Uasin Gishu & 10 & zone 1 & Zone 1 \\
S 10 & Nanyuki & 11 & Zone 1 & Zone 3 \\
S 11 & Nakuru & 13 & Zone 1 & Zone 1 \\
S 12 & Nakuru & 9 & Zone 1 & Zone 1 \\
S 13 & Nairobi & 12 & zone 2 & Zone 3 \\
S 14 & Kapsabet & 12 & Zone 1 & Zone 1 \\
S 15 & Kericho & 21 & Zone 2 & Zone 1 \\
S 16 & Kericho & 11 & Zone 2 & Zone 1 \\
S 17 & Mwingi & 20 & Zone 3 & Zone 3 \\
\hline
\end{tabular}

Table 2 provides the zoning criteria developed to facilitate grouping of the panels into common temperature and precipitation regions. Three zones were defined for temperature locations and two zones for precipitation.

Table 2. Climate Zoning of Samples Origin.

\begin{tabular}{llll}
\hline $\begin{array}{l}\text { Temperature } \\
\text { zone }\end{array}$ & $\begin{array}{l}\text { Annual } \\
\text { Temperature } \\
\text { Range }\left({ }^{\circ} \mathbf{C}\right)\end{array}$ & $\begin{array}{l}\text { Precipitation } \\
\text { Zone }\end{array}$ & $\begin{array}{l}\text { Annual Precipitation } \\
\text { Range (mm) }\end{array}$ \\
\hline Zone 1 & $\leq 17$ & Zone 1 & $>1000$ \\
Zone 2 & $<21,>17$ & & \\
Zone 3 & $\geq 21$ & Zone 3 & $<1000$ \\
\hline
\end{tabular}

Visual inspection was carried out on all of the PV module samples and each was found to exhibit several degradation effects as outlined in Table 3.

Table 3. Forms of degradation exhibited by solar module samples.

\begin{tabular}{ll}
\hline Module I.D & Degradation Forms \\
\hline & Electrochemical Corrosion; Browning, Hot spots, \\
S1 & $\begin{array}{l}\text { Delamination, junction box damage, cell discoloration, cell } \\
\text { interconnect degradation }\end{array}$ \\
& Browning, Cell discoloration, Cell fracture, Hot spots, \\
S2 & Delamination, cell interconnect degradation \\
& Browning, Cell fracture, Hot spots, Delamination, cell \\
S3 & interconnect degradation \\
& Browning, Cell discoloration, Hot spots, Cell fracture, cell \\
S4 & interconnect degradation \\
& junction box damage, Hot spots, Delamination \\
S5 & Electrochemical Corrosion; Cell discoloration Browning, \\
& hot spots, Delamination \\
S 6 & Electrochemical Corrosion; Browning, Cell fracture, hot \\
& spots, Delamination \\
S7 & Electrochemical Corrosion; Browning, Cell discoloration, \\
& Hot spot, cell interconnect degradation, Delamination \\
S8 & Cell fracture, cell interconnects degradation, junction box \\
damage Hot spots, Delamination
\end{tabular}




\section{Discussion}

Table 4 shows the magnitude of recurrence of each observed degradation form in the samples studied. Delamination of the encapsulate was seen to be the most predominant degradation effect, experienced by $82 \%$ of the samples. Hot spots and encapsulant browning were also noted to be common effects, being observed in $76 \%$ and $71 \%$ of the modules respectively.

Physical damages e.g front glass fracture and deformed junction box were observed to occur very minimally.

Table 4. Percentage prevalence of degradation forms in studied solar modules.

\begin{tabular}{ll}
\hline Degradation Effect & Percentage prominence in samples \\
\hline Browning & 71 \\
Cell discoloration & 41 \\
Electrochemical corrosion & 24 \\
Delamination & 82 \\
Hotspots & 76 \\
Cell fracture & 35 \\
Interconnects degradation & 24 \\
front glass fracture & 6 \\
deformed junction box & 12 \\
\hline
\end{tabular}

The primary degradation forms observed in the samples were those that affect the encapsulant i.e. delamination and encapsulant browning. Module delamination occurs as a result of the disintegration of bond between the encapsulant and other material layers that make up the PV module [12].

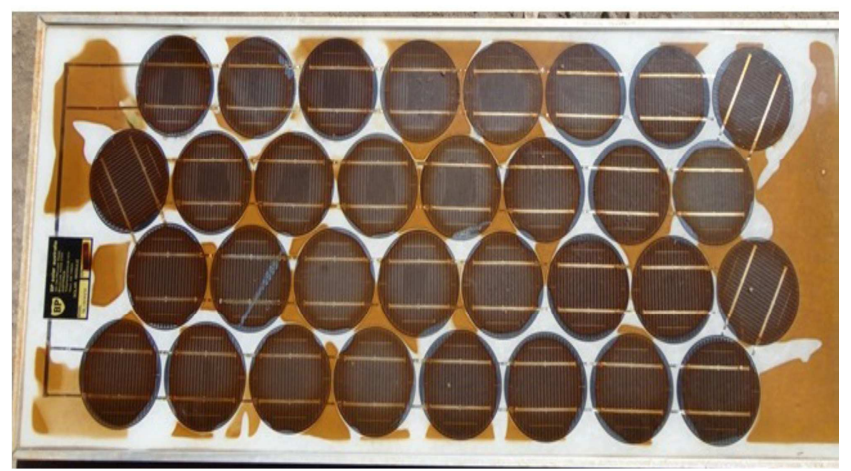

Figure 1. Destruction of laminate by water ingress.

Most of the delamination observed in the field has occurred at the interface between the encapsulant and the front surface of the solar cells in the module. A common observation has been that delamination is more frequent and more severe in hot and humid climates (Temperature zone 3 and Precipitation Zone 1).

The browning of EVA encapsulant used in PV modules with outdoor exposure was observed in several samples. Formulations of EVA that undergo yellowing/browning has been shown to produce acetic acid, with UV exposure which corrodes solder bonds and electrical contacts [13]. This also corresponds to increased leakage current through the encapsulant [12].

Hotspots were also observed as a common degradation form in many of the sample modules investigated. No climatic relation can be conclusively associated with the hotspots observed in the samples investigated in this research. However, the severe hotspots, for example those shown in Figure 2 below, were observed on panels which had not been ideally located and allowed some form of partial shading to the panel during the day.

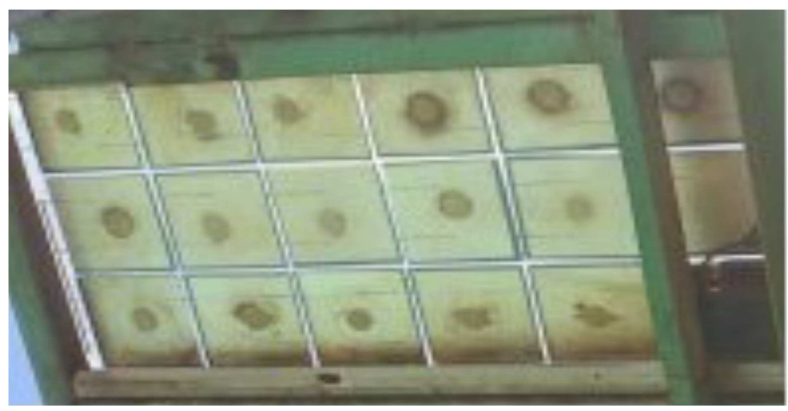

Figure 2. Hotspots on PV Module.

A number of samples were observed to have open-circuited inter-cell connections, broken solder joints and broken interconnects which may result from mechanical stresses. Mechanical stress on a module can sever the delicate ribbons and solder bonds. Reducing the number of available solder joints increases the series resistance and degrades performance which increases the possibility of hot spots and burn marks to form at solder joints, on the back sheet, and in the encapsulant [14].

Figure 3 shows junction box from one of the sample which had undergone warping of the cover, probably due to the high temperature conditions of the region. It was also installed directly on the corrugated iron sheets without allowing flow of air. As such, the junction box was exposed to elevated temperatures which consequently weakened the plastic cover

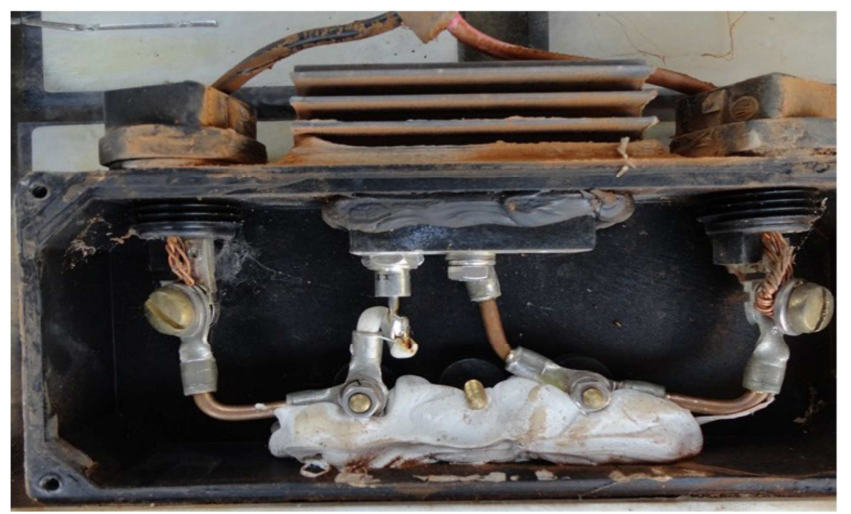

Figure 3. Junction box defects.

Glass breakage is an important degradation factor of PV modules. They occur in most of the cases during installation, maintenance, and especially during the transportation of modules to their installation sites [14]. 


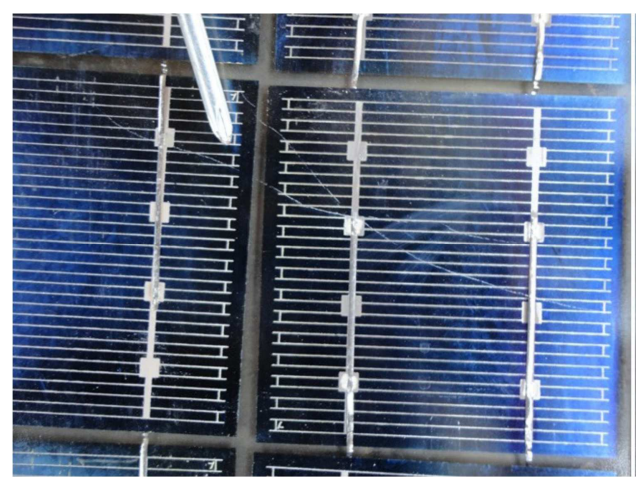

Figure 4. Cracked front glass of a solar module.

The broken modules or with cracks may keep functioning correctly. However, the risk of an electrical shock and of a moisture infiltration increases. Breakages and cracks are usually followed by other degradation types such as corrosion, discoloration and delamination [12].

Analysis was done to show the prevalence of each degradation form in each age cluster of the samples studied. Figure 5 (a-e), illustrates the results observed. Encapsulant browning was seen to be the most prevalent form of degradation in the 9-12 Years age clusters as illustrated in Figure 5(a). Figure 5(c) and 5(d) indicates that hot spots were observed to take place more commonly in the 17-20 and 21-24 Years age cluster. As only one panel existed in the 25-28 age clusters, the severeness of deformations in this group could not be determined. This panel exhibited all the forms of deformations observed in all the other panels.

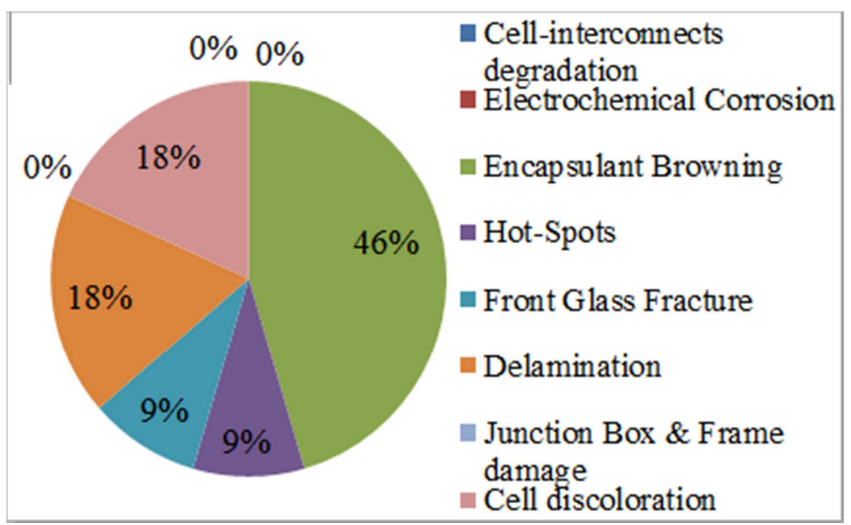

(a) 9 - 12 Years

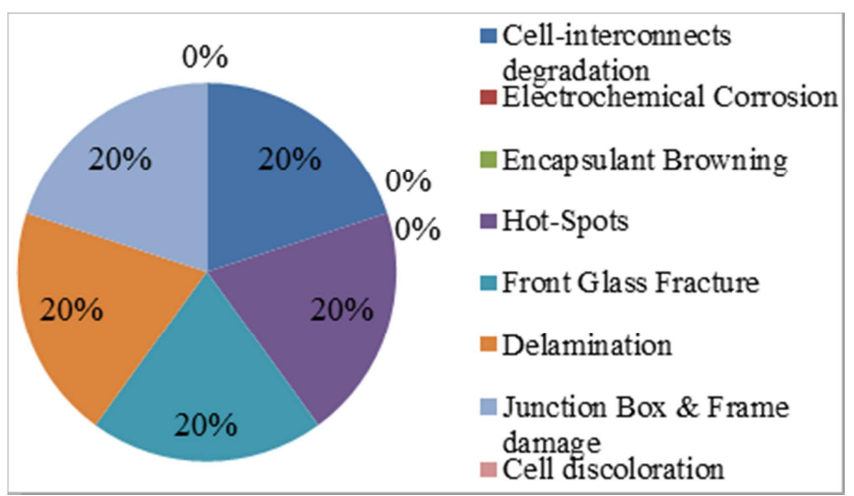

(b) 13 - 16 Years

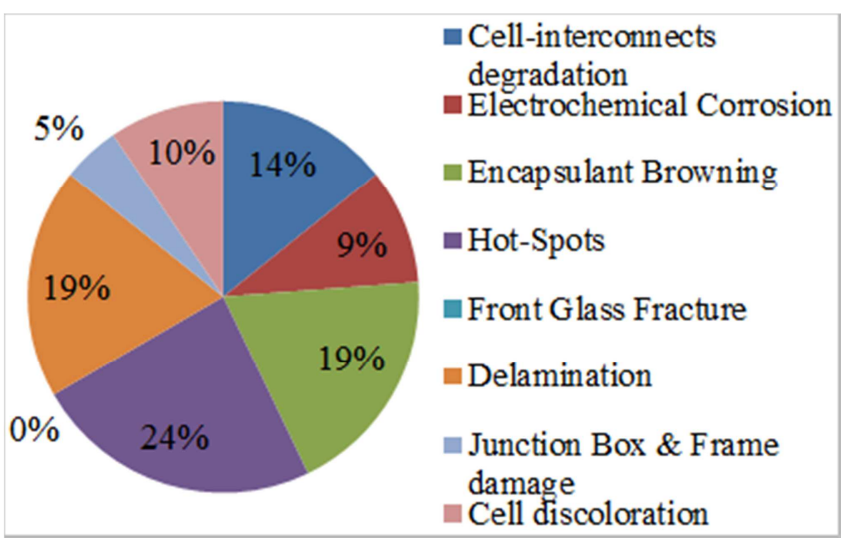

(c) 17 - 20 Years

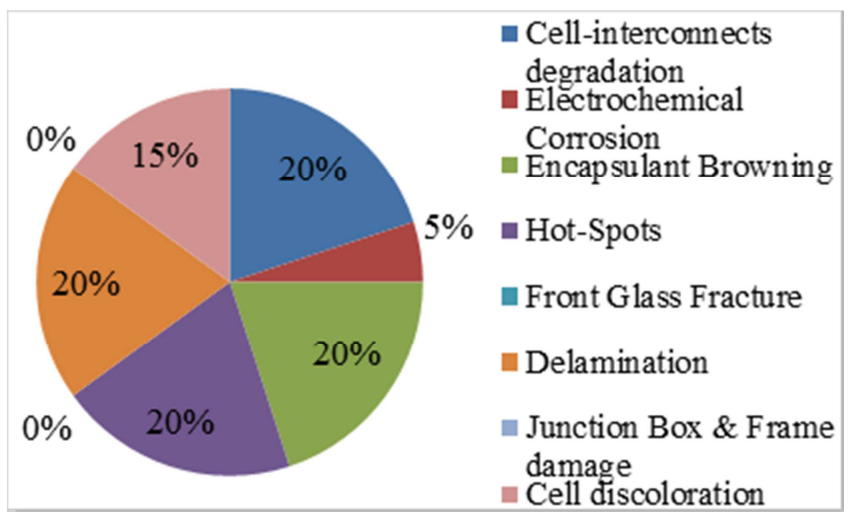

(d) 21 to 24 Years

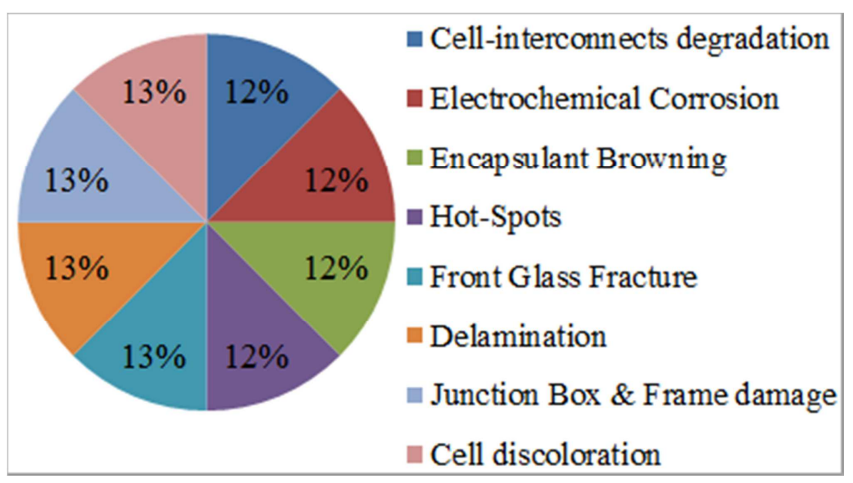

(e) 25 to 28 Years

Figure 5. Correlation between Degradation prevalence and age of solar panels.

\section{Conclusion}

The following conclusions were drawn after analysis of the results:

i). Main forms of degradation observed were defects on the encapsulant i.e. delamination and browning.

ii). Photovoltaic modules operating in regions of elevated temperatures experience more degradation forms.

iii). Photovoltaic modules operating in regions of higher annual mean precipitation exhibit more degradation forms as compared to those operating in areas of less humidity and moisture.

iv). A majority of solar systems which had been been 
installed more than nine years ago were poorly sized for the load they are feeding. Wrong balance of system components were used in the installations and there is almost complete absence of any maintenance routines carried out by the users of these systems.

\section{References}

[1] D.C Jordan and S.R Kurtz, "Photovoltaic degradation rates an analytical review," Progress in Photovoltaics: Research and Application, 2011.

[2] M. D. Kempe, "Modeling of rates of moisture ingress into photovoltaic modules", Solar Energy Materials and Solar Cells, vol. 90 , no. 16 , p. $27202738,2006$.

[3] K. Morita, T. Inoue, H. Kato, I. Tsuda, and Y. Hishikawa, "Degradation factor analysis of crystalline-Si PV modules through long-term field exposure test", in Proceedings of the 3rd World Conference on Photovoltaic Energy Conversion, p. 19481951, 2003.

[4] E. E. van Dyk, J. B. Chamel, and A. R. Gxasheka, "Investigation of delamination in an edge-defined film-fed growth photovoltaic module," Solar Energy Materials and Solar Cells, vol. 88, no. 4, p. 403411, 2005.

[5] N. G. Dhere and N. R. Raravikar, "Adhesional shear strength and surface analysis of a PV module deployed in harsh coastal climate," Solar Energy Materials and Solar Cells,vol. 67, no. 1-4, pp. $363\{367,2001$.

[6] X. Han, Y.Wang, L. Zhu, H. Xiang, and H. Zhang, "Mechanism study of the electrical per formance change of silicon concentrator solar cells immersed in de-ionized water," Energy Conversion and Management, vol. 53, no. 1, pp. 1-10, 2012.
[7] D. Polverini, M. Field, E. Dunlop, and W. Zaaiman, "polycrystalline silicon PV modules performance and degradation over 20 years," Progress in Photovoltaics: Research and Applications, vol. 21, no. 5, pp. 1004-1015, 2013.

[8] M. Kontges, V. Jung, and U. Eitner, "Requirements on metallization schemes on solar cells with focus on photovoltaic modules," in Proceedings of the 2nd Workshop on Metallization of Crystalline Silicon Solar Cells, 2010.

[9] C. Dechthummarong, B. Wiengmoon, D. C. and C. Jivacate, and K. Kirtikara, "Physical deterioration of encapsulation and electrical insulation properties of PV modules after longterm operation in thailand," Solar Energy Materials and Solar Cells, vol. 94, no. 9, pp. $1437\{1440,2010$.

[10] W. Short, D. Packey, and T.Holt, "A manual for the economic evaluation of energy efficiency and renewable energy technologies," Report NREL/TP-462-5173, 1995.

[11] L. Meeker WQ, Statistical Methods for Reliability Data. Jo. John Wiley \& Sons: New York, 1998.

[12] M.A Quintana, D.L King and T.J McMahon and C.R Osterwald, "Commonly observed degradation in field-aged photovoltaic modules", IEEE Photovoltaic Specialist Conference, 2002.

[13] M. D. Kempe, G. J. Jorgensen, K. M. Terwilliger, T. J. McMahon, C. E. Kennedy, and M. D. Kempe, "Acetic acid production and glass transition concerns with ethylene-vinyl acetate used in photovoltaic devices", Solar Energy Materials and Solar Cells, 2007.

[14] D.W Cunningham, P. Monus and J. Miller, "Long term reliability of PV modules",In: Proc. 20th European Photovoltaic Solar Energy Conference, 2005. 